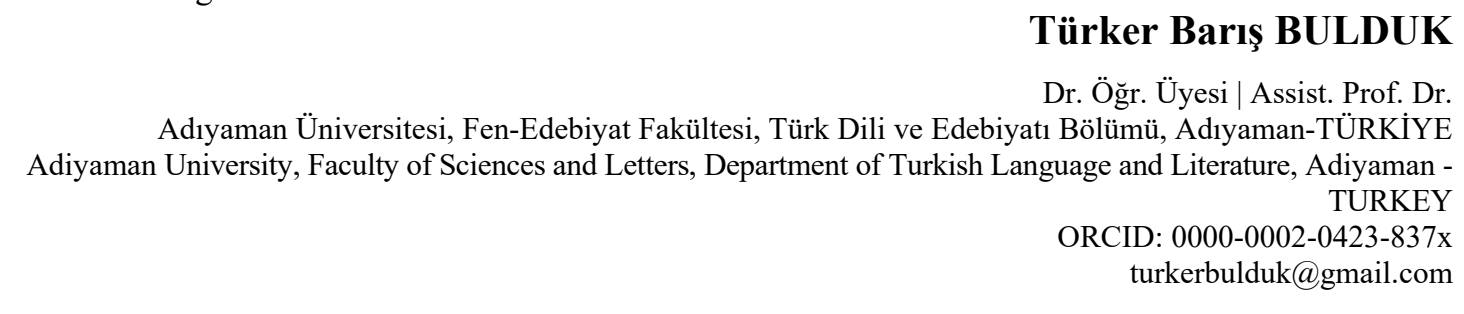

\title{
Gümüşhane İli ve Yöresi Ă̆ızları Söz Varlığında Eski Türkçe Kelimeler
}

$\ddot{O} z$

Türkiye Türkçesinin en önemli zenginliklerinden biri olan ağızlar, bünyelerinde barındırdıkları farklı birçok ses ve şekil özellikleriyle Türkçe kelimelerin değişim ve gelişim çizgisini ortaya koymada belirleyici bir rol oynamaktadır. Yazı dilinde olmayan birçok ses, şekil ve kelimeye ağızlarda rastlamak mümkündür. Gümüşhane ili ve yöresi de köklü geçmişi ve bölgede yaşayan halkın yapısı itibariyle zengin ağız bölgelerimizden biridir. Bu çalışmada Gümüşhane ili ve yöresi ağızlarında varlığını sürdüren Eski Türkçe kelimeler ortaya konulacaktır.

Eski Türkçe, Türk yazı dilinin tarihî dönemlerinden ilki olup bu dönemde ortaya konulan yazılı eserler Türkçeye kaynaklık etmektedir. Bu döneme ait Köktürkçe ve Uygurca metinlerde kullanılan söz varlığı konuştuğumuz Türkçenin temelini oluşturmaktadır. Eski Türkçeye ait söz varlığının birçoğu çeşitli nedenlere bağli olarak (zaman, din değişikliği, göç hareketleri vb.) ya ses ve/veya şekil değişikliğine uğramış ya da unutulmuştur. Bugün bu söz varlığına ait kelimelerin bir kısmı yazı dilinde olmamasına rağmen ağızlarda yaşamaya devam etmektedir. Zengin kültürümüz içerisinde önemli bir yeri olan bu kelimelerin ortaya konulması unutulup kullanımdan düşmelerini engelleyecektir.

Anahtar Kelimeler: Ağız, Gümüşhane Ağzı, Eski Türkçe, Türkiye Türkçesi, Söz Varlığı.

\section{Old Turkish Words in Vocabulary of Gümüşhane Province and its Neighourhood Dialects}

\begin{abstract}
The dialects, which are one of the most important richness of Turkey Turkish, play a decisive role in revealing the line of change and development of Turkish words with their different sound and shape features. It is possible to come across many sounds, patterns and words in dialects which are not in existing in written language. Gümüşhane province and its vicinity is one of our rich dialect regions with its long history and the structure of the people living in the region. In this study, the old Turkish words that continue their presence in the dialects of Gümüşhane province will be revealed.

The first works written in the old Turkish period, which is one of the historical periods of Turkish written language, are the sources of modern Turkish. The vocabulary used in the Kokturkish and Uighur texts of this period is the basis of the Turkish language we speak. Many of the vocabulary of Old Turkish has been changed or forgotten due to various reasons (time, change of religion, migration movements, etc.). Today, although some of the words belonging to this vocabulary do not exist in the written language, they still continue to live in the dialects. The revelation of these words, which have an important place in our rich culture, will prevent these words from falling into disuse.
\end{abstract}

Keywords: Dialect, Gümüşhane Dialect, Old Turkish, Turkey Turkish, Vocabulary. 


\section{Türker Barış BULDUK, “Gümüşhane İli ve Yöresi Ağızları Söz Varlı̆ğında Eski Türkçe Kelimeler", Mavi Atlas, 7(1)/2019: 52-67.}

\section{Giriş}

Gümüşhane, coğrafî olarak İpek Yolu üzerinde bulunduğu için hep bir geçiş bölgesi olmuş ve buna bağlı olarak tarih boyunca birçok medeniyete ev sahipliği yapmıştır. Gümüşhane'nin özellikle Trabzon-Erzurum-Tebriz anayolu üzerinde bulunması sosyo-ekonomik olarak önem kazanmasını sağlamıştır. Türklerin XI. yüzyıldan itibaren yoğunlaşan Orta Asya'dan batıya göç hareketlerinin durak yerlerinden birisi de coğrafî konumuna bağlı olarak Gümüşhane olmuştur.

Tarihî kaynakların verdiği bilgiler, Oğuzlar üzerinde yapılan araştırmalar, arşiv kaynaklarından ve yer adları incelemelerinden ortaya çıkan sonuçlar, Anadolu'ya Oğuzların 24 boyundan 23'ünün göç etmiş olduğunu ortaya koymaktadır (Sümer 1992: 173). Anadolu'yu yurt edinen bu Oğuz boyları Anadolu'nun ve Rumeli'nin çeşitli bölgelerine yayılmışlardır.

Oğuz-Türkmen boyları ile bunlara bağlı oymak ve aşiretlerin daha o zamandan mevcut birtakım ağız farklılıklarının bulunması ve yurt edindikleri bölgelerde de farklı Oğuz-Türkmen boyları ile etkileşim kurmaları Anadolu ve Rumeli coğrafyasında birbirinden ses, şekil ve söz varlığı açısından farklı birçok ağız bölgesinin oluşmasına neden olmuştur. Bu bakımdan Türkiye Türkçesi ağızları, dil incelemelerine kaynaklık eden bir konumda bulunmaktadır. Ağızlarda varlığını sürdüren birçok ses ve şekil özelliği ile kelime, yazı dilinde bulunmamaktadır. Bu ses, şekil ve kelimelerin Eski Türkçeden bugüne, yazı dilinden farklı olarak, ağızlarda hâlâ kullanılıyor olması Türkçeye kaynak bakımından önemli bir zenginlik katmaktadır.

Eski Türkçe, Türk yazı dilinin tarihî dönemlerinin ilkidir. Köktürkçe ve Uygurca metinlerin ortaya konulduğu bu dönem, bugün konuşulan Türkçenin temelini oluşturmaktadır. Eski Türkçeye ait birçok ses ve şekil özelliği ile kelime, bugün ya değişikliğe uğramış ya da unutulup kullanımdan düşmüştür. Bu çalışma ile Anadolu'da tarihî ve coğrafî konumu itibariyle önemli bir yeri bulunan Gümüşhane ili ve yöresindeki ağızlarda varlığını devam ettiren Eski Türkçe kelimeler tespit edilecektir. Böylece bu kelimelerin de zamanla unutulmalarının önüne geçilecek ve Türkçenin zenginliği içinde yer bulmaları sağlanacaktır.

Gümüşhane ili ve yöresi söz varlığıyla ilgili en kapsamlı çalışma Dr. Serdar Bulut'un “Gümüşhane İli ve Yöresi Ağızları Söz Varlığı” eseridir. Bu eserinde Bulut, Gümüşhane ili ve yöresi ile ilgili hazırlanmış bütün dil ve kültür eserlerinin yanında Derleme Sözlüğü'nü de incelemiş ve 4230'u Derleme Sözlüğü'nden olmak üzere 6030 madde başından oluşan bir söz varlığına ulaşmıştır. 


\section{2. İnceleme}

Dr. Serdar Bulut'un “Gümüşhane İli ve Yöresi Ağızları Söz Varlığı” eseri Gümüşhane'nin söz varlığı ile ilgili hazırlanmış en kapsamlı çalışmadır. Bu eserde madde başı olarak kullanılan kelime ve kelime grupları bu çalışmada ele alınacaktır.

Gümüşhane ili ve yöresi ağılarında kullanılan kelimelerin bir kısmı anlam ve şekil bakımından Eski Türkçedeki kullanımıyla aynıdır. Bir kısmı ise taşıdığı anlamı muhafaza ederken şekil hususunda küçük ses değişikliklerine uğramıştır. Bölgede Eski Türkçedeki şekliyle kullanılan kelimelerle, kısmî ses değişikliklerine uğramış kelimeler ayrı başlık altında incelenecektir.

Bugün Türkiye Türkçesinde de Eski Türkçedeki kullanımını devam ettiren birçok kelime bulunmaktadır. Gümüşhane ili ve yöresi söz varlığında kullanılan "alım, altın, arı, bağır, baş, beşik, bilezik, burun, ense, gelin, gök, gün, güz, hatun, 1rak, kendi, odun, ortak, samanlık, söz, su, tok, uslu, yalınız, yaman, yiğit” gibi kelimeler Türkiye Türkçesinde de sıklıkla kullanılan Eski Türkçe kelimelerdir. Bu çalışmada bu gibi kelimelere yer verilmeyecek, Gümüşhane ağzında kullanılan ancak Türkçe Sözlük’te bulunmayan Eski Türkçe kelimeler anlamlarıyla birlikte alfabetik bir biçimde verilecektir. Yine Türkçe Sözlük'te ve Gümüşhane ağzında bulunmasına rağmen fazla kullanılmadığı için unutulmaya başlamış olan Eski Türkçe kelimeler ayrı bir başlık altında verilecektir. Böylece Türkçe kökenli bu kelimelerin unutulmasının önüne geçilmesi amaçlanmaktadır.

Bu çalışmada, Eski Türkçe ve Gümüşhane ili ve yöresi ağızlarında benzerlik gösteren kelimeler iki grupta ele alınmıştır:

\subsection{Gümüşhane İli ve Yöresi Ağızları Söz Varlığında Bulunup Türkçe Sözlük’te Bulunmayan Eski Türkçe Kelimeler:}

Gümüşhane ağzındaki Eski Türkçe kelimelerden bazıları Türkçe Sözlük’te herhangi bir şekilde bulunmamaktadır. Bazı kelimeler ise Gümüşhane ağzında farklı bir kullanım özelliği kazandıkları (ses değişimi veya gelişimi) için Türkçe Sözlük’te bulunmamaktadır. Dolayısıyla, Gümüşhane ağzında bulunup Türkçe Sözlük’te bulunmayan Eski Türkçe kelimeler bu çalışmada iki başlık altında sınıflandırılacaktır:

\subsubsection{Türkçe Sözlük’te Bulunmayan Eski Türkçe Kelimeler:}

Gümüşhane ağzında kullanılan kelimelerin bazıları, ses değiş̧ikliğine veya gelişimine uğrayıp uğramadıklarına bakılmaksızın, Türkçe Sözlük’te bulunmamaktadır. Ağızlarda varlığını devam ettiren ve her biri binlerce yıllık bir geçmişe sahip bu 
kelimelere Türkçe Sözlük'te yer verilmesi ve bu kelimelerin yazı dilimizde de kullanımlarının sağlanması unutulmalarının önüne geçecektir. Bu kelimeler şunlardır:

al (ET) / aldamak (GA): al kelimesi Eski Türkçede "hile" anlamiyla (Gülensoy 2011: 61) kullanılmıştır. Bu kelimeden türeyen aldamak kelimesi de Gümüşhane ağzında "kandırmak, aldatmak" anlamlarıyla (Bulut 2018: 16) kullanılmıştır.

aruḳuru-arkuru (ET) / arḩuru (GA): Kelime "çapraz, dolambaçlı" anlamlarıyla kullanılmıştır. (Caferoğlu 2015: 20, Paçacıoğlu 2016: 72; Bulut 2018: 24).

askırmak-asurmak (ET) / ansırmak (GA): Kelime, "hapşırmak" anlamıyla kullanılmıştır (Gülensoy 2011: 60; Bulut 2018: 22).

baya-bayaḳı (ET) / bayah (GA): Kelime, "önce, evvelce" anlamlarıyla kullanılmıştır (Caferoğlu 2015: 36; Bulut 2018: 42).

bäkütmäk-bärkirmäk (ET) / bekiştirmek (GA): Eski Türkçede "sağlamlaştırmak, berkitmek" anlamlarıyla (Caferoğlu 2015: 38, 39) kullanılan kelime Gümüşhane ağzında aynı kökten gelip küçük bir değişikliğe uğrayarak yine Eski Türkçedeki anlamlarıyla kullanılmıştır (Bulut 2018: 45).

birki-biriki (ET) / birkük (GA): Eski Türkçede "birleşik" anlamıyla (Tekin 2000: 241, Paçacıoğlu 2016: 131) kullanılan kelime Gümüşhane ağzında "bir araya gelmiş" anlamıyla (Bulut 2018: 54) kullanılmıştır.

bolmaḳ (ET) / bola ki (GA): Kelime, “olmak” anlamıyla kullanılmıştır (Caferoğlu 2015: 47; Bulut 2018: 55).

çanaḳ (ET) / çanak (GA): Kelime, Eski Türkçede “ölçü kabı” anlamıyla (Caferoğlu 2015: 59) kullanılırken Gümüşhane ağzında "terazi” anlamıyla (Bulut 2018: 87) kullanılmıştır.

çeç (ET) / çeç (GA): Kelimenin "balsız petek dalağı, balmumu” anlamlarıyla kullanıldığı görülmektedir (Gülensoy 2011: 226; Bulut 2018: 91).

çıvga (ET) / çıvga (GA): Kelime, Eski Türkçede "ökse çubuğu” anlamıyla (Caferoğlu 2015: 62) kullanılırken Gümüşhane ağzında “ince, düzgün ve budaksız çubuk" anlamıyla (Bulut 2018: 102) kullanılmıştır.

daruġa (ET) / daruğa (GA): Kelime, Eski Türkçede "bir memuriyet adı" anlamıyla (Caferoğlu 2015: 67) kullanılırken Gümüşhane ağzında "askerî vali” anlamıyla (Bulut 2018: 116) kullanılmıştır. 
äçä (ET) / ece (GA): Kelime, "büyük kardeş, ağabey" anlamlarıyla kullanılmıştır (Caferoğlu 2015: 68; Bulut 2018: 141).

älik (ET) / eliyh (GA): Kelime, Eski Türkçede "geyik" anlamıyla (Tekin 2000: 241) kullanılırken Gümüşhane ağzında "dağ keçisi, karaca” anlamlarıyla (Bulut 2018: 146) kullanılmıştır.

haçan-ḳaçan (ET) / haçan (GA): Kelime, "ne zaman, ne vakit" anlamlarıyla kullanılmıştır (Caferoğlu 2015: 81; Bulut 2018: 219).

içi (ET) / ici (GA): Kelime, Eski Türkçede "ağabey" anlamıyla (Caferoğlu 2015: 88; Orkun 2011: 802; Tekin 2000: 244) kullanılırken Gümüşhane ağzında "kardeş, baba" anlamlarıyla (Bulut 2018: 252) kullanılmıştır.

ḳını̀ / ḳınmaḳ (ET) / kınıklamak (GA): Kelime, Eski Türkçede isim olarak ḳını̀ şekliyle ve "şiddetli arzu" anlamıyla ve fiil olarak ḳınmak şekliyle (Caferoğlu 2015: 175) kullanılırken Gümüşhane ağzında yine kıın-kökünden türeyerek kınıklamak şeklinde ve "bir şeye aşırı derecede düşkün olmak, tutkun olmak" anlamlarıyla (Bulut 2018: 273) kullanılmıştır.

köpmek (ET) / köpmek (GA): Kelime, "toprağın tavlanması, şişmek, kabarmak" anlamlarıyla kullanılmıştır (Gülensoy 2011: 554; Bulut 2018: 281).

kümäk (ET) / kümek (GA): Kelime, Eski Türkçede fiil olarak ve "muhafaza etmek, saklamak, korumak" anlamlarıyla (Caferoğlu 2015: 121) kullanılırken Gümüşhane ağzında isim olarak fakat Eski Türkçedeki anlamına yakın bir şekilde "yardım, imdat" anlamlarıyla (Bulut 2018: 287) kullanılmıştır.

nälük (ET) / nelik (GA): Kelime, Eski Türkçede nälük / nälök şekillerinde "niçin, nasıl, ne gibi” anlamlarıyla (Caferoğlu 2015: 136; Tekin 2000: 250; Orkun 2011: 820) kullanılmıştır. Kelimeye Gümüşhane ağzında neliyh şeklinde de rastlanmaktadır ve "niçin, neye, neden” anlamlarıyla (Bulut 2018: 312) kullanılmıştır.

sarsag (ET) / sarsak (GA): Kelime, Eski Uygur Türkçesi metinlerinde "kaba, kötü" anlamlarıyla (Caferoğlu 2015: 197) kullanılmıştır. Aynı kelimeye Gümüşhane ağzında “dağınık, ahmak" anlamlarıyla (Bulut 2015: 338) rastlanmaktadır.

sıḳamaḳ (ET) / sıhalmak (GA): Kelime, Eski Uygur Türkçesi metinlerinde "sıklaştırmak, kalınlaştırmak" anlamlarıyla (Caferoğlu 2015: 202) kullanılmıştır. Gümüşhane ağzında ise Eski Türkçedeki kullanımıyla aynı kökten türeyerek "sıklaşmak" anlamıyla (Bulut 2018: 343) kullanılmıştır. 
sin (ET) / sinci (GA): Eski Uygur Türkçesi metinlerinde sin şekliyle ve "bir ölçü çeşidi" anlamıyla (Caferoğlu 2015: 205) kullanılmıştır. Gümüşhane ağzında Eski Türkçedeki kullanımından türeyerek "duyarlı tartı aracı, terazi” anlamlarıyla (Bulut 2018: 346) kullanılmıştır.

suvamaḳ (ET) / suvumak (GA): Kelime, "sıvamak" anlamıyla kullanılmıştır (Caferoğlu 2015: 213; Bulut 2018: 350).

şor (ET) / şor (GA): Kelime, "tuzlu” anlamıyla kullanılmıştır (Caferoğlu 2015: 218; Bulut 2018: 358).

taġar (ET) / tağar (GA): Kelime, Eski Uygur metinlerinde "torba" anlamıyla (Caferoğlu 2015: 219) kullanılmıştır. Gümüşhane ağzında Eski Türkçedeki kullanımına benzer şekilde "lazımlık, oturak" anlamlarıyla (Bulut 2018: 360) kullanılmıştır.

täyän (ET) / teyin (GA): Eski Türkçede täyän şeklinde ve "sincap" anlamıyla (Tekin 2000: 254; Orkun 2011: 862) kullanılan kelime, aynı anlamıyla ve teyin şeklinde (Bulut 2018: 369) Gümüşhane ağzında görülmektedir.

tezmäk (ET) / tezmek (GA): Eski Türkçede "kaçmak" anlamıyla (Orkun 2011: 862) kullanılan bu kelimeye Gümüşhane ağzında Eski Türkçedeki anlamına yakın bir şekilde “izini kaybetmek” (Bulut 2018: 369) olarak rastlanmaktadır.

tikişmäk (ET) / tikişme (GA): Eski Türkçede "itişmek, kakışmak, vuruşmak" anlamlarıyla (Caferoğlu 2015: 239) kullanılan kelime Gümüşhane ağzında Eski Türkçedeki anlamlarına yakın bir şekilde "tartışma, inatlaşma" anlamlarıyla (Bulut 2018: 372) kullanılmıştır.

ulam (ET) / ulam ulam (GA): Eski Uygur metinlerinde "daimi, kesiksiz" anlamlarıyla (Caferoğlu 2015: 264) kullanılan kelime Gümüşhane ağzında "acele acele, çabucak kaçıp uzaklaşmak" anlamıyla ve ikileme olarak (Bulut 2018: 377) kullanılmıştır. Eski Türkçedeki anlam ile Gümüşhane ağzındaki anlamın yakın olduğu görülmektedir.

ürmäk (ET) / ürmek (GA): Kelime, Eski Türkçede ve Gümüşhane ağzında "havlamak" anlamıyla kullanılmıştır (Caferoğlu 2015: 273; Bulut 2018: 381).

yanmaḳ (ET) / yannamah (GA): Eski Uygur Türkçesinde yanmak kelimesi "dönmek, geri gelmek" anlamlarıyla (Caferoğlu 2015: 284) kullanılmıştır. Bu kelimeden türeyen yannamah̆ kelimesinin de Gümüşhane ağzında yine Eski Türkçedeki gibi "dönmek” anlamıyla (Bulut 2018: 391) kullanıldığı görülmektedir. 
yonmaḳ (ET) / yonmak (GA): Bu kelime Eski Uygur Türkçesi metinlerinde "yaralamak, yok etmek, ziyana sokmak, silmek" anlamıyla (Caferoğlu 2015: 302, Paçacıŏlu 2016: 794) kullanılmıştır. Kelime, Gümüşhane ağzında ise aynı şekliyle kullanılmış ve "sahibinin haberi olmadan bahçeden bir şeyler koparmak" anlamını (Bulut 2018: 401) taşımıştır. $\mathrm{Bu}$ iki kelimenin, taşıdıkları yakın anlam nedeniyle, ortak oldukları düşünülmektedir.

yükünmäk-yükinmäk (ET) / yükenmek (GA): yükünmäk kelimesi Eski Türkçede "secde etmek, eğilmek, diz çökmek" anlamlarında (Caferoğlu 2015: 306, Paçacıŏlu 2016: 811, Orkun 2011: 900; Tekin 2000: 260) kullanılmıştır. Aynı kelime Gümüşhane ağzında ise $\ddot{u}$ yuvarlak ünlüsünün düzleşip $e$ ünlüsüne dönüşmesiyle yükenmek şeklini almış ve yine "secde etmek" anlamında (Bulut 2018: 402) kullanılmıştır.

\subsubsection{Ses Değişikliği Nedeniyle Türkçe Sözlük’te Bulunmayan Eski Türkçe Kelimeler:}

Gümüşhane ağzında kullanılan Eski Türkçe kelimelerin bazıları çeşitli ses değişimlerine veya gelişimlerine uğramıştır. $\mathrm{Bu}$ nedenle Türkçe Sözlük'te bulunmamaktadır. Örneğin, Türkçe Sözlük’teki ayrık kelimesi Gümüşhane ağzında ayruh şekliyle; ăğışak kelimesi Gümüşhane ağzında ă̆ırşah şekliyle; boya kelimesi Gümüşhane ağzında boyah şekliyle; töre kelimesi Gümüşhane ağzında türe şekliyle bulunmaktadır. Gümüşhane ağzında bulunan fakat ses değişikliği nedeniyle Türkçe Sözlük'te bulunmayan kelimeler şunlardır:

adruk (ET) / ayruh (GA): Eski Türkçede ve Gümüşhane ağzında bu kelimenin "fark, farklı, ayrı" anlamlarıyla kullanıldı̆̆ı görülmektedir (Gülensoy 2011: 96; Bulut 2018: 33).

ag̉ırçaḳ (ET) / ağırşah (GA): Kelime, "iğin rahatça eğrilmesini sağlamak için alt tarafına geçirilen tahta veya kemikten yuvarlak parça” anlamıla (Gülensoy 2011: 54; Bulut 2018: 8) kullanılmıştır.

ạ̣tarmaḳ (ET) / ahtarmak (GA): Eski Türkçede “dönmek, çevirmek” anlamlarıyla (Caferoğlu 2015: 9) kullanılan kelime Gümüşhane ağzında "karıştırmak, çevirmek, altüst etmek” anlamlarıyla (Bulut 2018: 12) kullanılmıştır.

azġurmak (ET) / azdurmak (GA): Kelime, "yanlış yola götürmek, azdırmak, saptırmak" anlamlarıyla kullanılmıştır (Caferoğlu 2015: 28; Bulut 2018: 34).

azuḳ (ET) / azuh (GA): Kelime, “erzak” anlamılla kullanılmıştır (Caferoğlu 2015: 29; Bulut 2018: 34). 
boduġ-boy (ET) / boyah (GA): Eski Türkçede bodug veya boy şekillerinde ve "boya, renk" anlamlarıyla (Caferoğlu 2015: 49) kullanılan kelimenin aynı kökten türeyerek Gümüşhane ağzında boyah şeklinde ve yine "boya" anlamıyla (Bulut 2018: 56) kullanıldığı görülmektedir.

boġuz (ET) / boğoz (GA): Kelime, "boğaz" anlamıyla kullanılmıştır (Caferoğlu 2015: 46; Bulut 2018: 55).

çıbık-çubik (ET) / çıbık (GA): Kelime, "çubuk" anlamıyla kullanılmıştır (Caferoğlu 2015: 66, Paçacioğlu 2016: 185; Bulut 2018: 98).

çigidäm (ET) / çiydem (GA): Kelime, "çiğdem veya bir bitki türü” anlamlarıyla kullanılmıştır (Caferoğlu 2015: 62; Bulut 2018: 105).

itig (ET) / itük (GA): Kelime, "kayıp, kayıp olan şey" anlamlarıyla kullanılmıştır (Caferoğlu 2015: 101; Bulut 2018: 259).

kaytarmak (ET) / gaytarmak (GA): Kelimenin "yöneltisinden döndürmek, çevirmek, işten kaçmak" anlamlarıyla kullanıldığg görülmektedir (Gülensoy 2011: 357; Bulut 2018: 187).

kegirmek (ET) / gegirmek (GA): Kelime, "midede toplanan gazı sesle ağızdan çıkarmak” anlamıyla kullanılmıştır (Gülensoy 2011: 360; Bulut 2018: 189).

körümçi (ET) / görüm (GA): Kelimenin "kocanın kız kardeşi” anlamıyla kullanıldığ1 görülmektedir (Gülensoy 2011: 385; Bulut 2018: 211).

sasıg / sasımaḳ (ET) / sasuh çalmak (GA): Eski Uygur Türkçesi metinlerinde "çürük, kokmuş" anlamlarıyla (Caferoğlu 2015: 198) kullanılan kelime, Gümüşhane ağzında Eski Türkçedeki kullanımıyla aynı kökten türeyerek "yăg, peynir vb. yiyeceklerin az kokuşması" (Bulut 2018: 339) anlamıyla kullanılmıştır.

talamaḳ (ET) / talamah (GA): Kelime, "yağmalamak" anlamıyla kullanılmıștır (Caferoğlu 2015: 221; Bulut 2018: 361).

tirig (ET) / tiri (GA): Kelime, "diri, canlı, hayat" anlamlarıyla kullanılmıştır (Orkun 2011: 865; Tekin 2000: 254; Bulut 2018: 372). Eski Türkçede tirig şeklinde kullanılan kelimenin sonundaki $g$ konsonantı Batı Türkçesinde düşmüştür.

toy (ET) / töy (GA): Kelime, "şölen, bayram" anlamlarıyla kullanılmıştır (Gülensoy 2011: 928; Bulut 2018: 374). 
törçimäk-törümäk (ET) / töremek (GA): Eski Uygur Türkçesi metinlerinde törçimäk veya törümäk şekillerinde rastladığımız kelime, "türemek, doğmak, neşet etmek" anlamlarıyla (Caferoğlu 2015: 249; Tekin 2000: 255) kullanılmıştır. Aynı kelimenin Gümüşhane ağzında Eski Türkçedeki anlam özellikleriyle ve töremek şeklinde kullanıldığ1 (Bulut 2018: 374) görülmektedir.

törü (ET) / türe (GA): Kelime, "gelenek, görenek, örf” anlamlarıyla kullanılmıştır (Gülensoy 2011: 947; Bulut 2018: 375).

yaşmaḳ (ET) / yaşmah (GA): Eski Uygur Türkçesinde yaşmaḳ kelimesi "gizlenmek, saklanmak" anlamlarıyla (Caferoğlu 2015: 290) kullanılmıştır. Gümüşhane ağzında ise aynı kelime isim şeklinde ve "başla birlikte yüzü, ağzı kapatan örtü" anlamında kullanılmıştır (Bulut 2018: 394). Gümüşhane ağzındaki kullanımın Eski Türkçedeki kullanımın isim hâline gelmiş şekli olduğu düşünülmektedir, çünkü anlamlar arasında bir benzerlik söz konusudur.

yitmäk (ET) / yitük (GA): Eski Türkçede yitmäk kelimesi "kaybolmak" anlamıyla (Caferoğlu 2015: 299) kullanılmıştır. Bu kelimeden türeyen yitük kelimesi ise yine Gümüşhane ağzında "kaybolmuş" anlamıyla (Bulut 2018: 400) kullanılmıştır.

yoḳaru (ET) / yokarı (GA): Kelimenin hem Eski Türkçede hem de Gümüşhane ağzında "yukarı anlamıyla kullanıldığı görülmektedir (Caferoğlu 2015: 301; Bulut 2018: 400).

\subsection{Gümüşhane İli ve Yöresi Ağızları Söz Varlığında ve Türkçe Sözlük’te Bulunan Eski Türkçe Kelimeler:}

Türkçe Sözlük’te, doğal olarak, Eski Türkçedeki kullanımı devam ettiren birçok kelime bulunmaktadır. Bu kelimelerin bir kısmı "alım, altın, arı, bağır, baş, beşik, bilezik, burun, ense, gelin, gök, gün, güz, hatun, ırak, kendi, odun, ortak, samanlık, söz, su, tok, uslu, yalınız, yaman, yiğit” gibi Gümüşhane ili ve yöresi söz varlığında da karşılaştığımız çokça bilinen ve kullanılan kelimelerdir. Bir kısmı da kullanılmadığ 1 için artık unutulmaya yüz tutmuş olan kelimelerdir. Bu başlıkta, Gümüşhane ili ve yöresi söz varlığında rastlanılan, fakat Türkiye Türkçesinde yaygın olmayan kelimelere değinilmektedir. Bu nitelikteki kelimeler şunlardır:

aba (ET) / aba (GA): Eski Türkçede "abla, anne” anlamlarıyla (Gülensoy 2011: 43) kullanılan aba kelimesi Gümüşhane ağzında da aynı şekil ve anlamını muhafaza etmiştir (Bulut 2018: 3).

adġır (ET) / aygır (GA): Kelime, Eski Türkçede adġır şeklinde ve "damızlık erkek at" anlamıyla (Gülensoy 2011: 93) kullanılmıştır. Gümüşhane ağzında ise kelime içinde $d>$ 
$y$ değişikliği ile aygır şeklinde ve "iki yaşından büyük erkek binek, at" anlamıyla (Bulut 2018: 32) kullanılmıştır.

ag̉namak (ET) / ağnamak (GA): Eski Türkçede "arkası üstü yere sürtünmek, debelenmek, kıvranmak" anlamıyla (Caferoğlu 2015: 7) kullanılan kelime Gümüşhane'de “eşeklerin, atların, katırların tozlu bir yer buldukları zaman yatıp yuvarlanmaları" anlamıyla (Bulut 2018: 9) kullanılmıştır.

aġu (ET) / ağu (GA): “Zehir” anlamıyla kullanılan kelimeye Köktürk metinlerinde de rastlanmaktadır (Tekin 2000: 237).

aka (ET) / aka (GA): Kelime, "büyük kardeş, ağabey” anlamlarıyla kullanılmıştır (Caferoğlu 2015: 9; Bulut 2018: 12).

ala (ET) / ala (GA): Kelime "ela" anlamıyla kullanılmıştır, aynı kullanıma Köktürk döneminde de rastlanmaktadır (Orkun 2011: 758).

alkış (ET) / alkış vermek (GA): Eski Türkçede “övme, kutlama, hayır dua” anlamlarıyla (Caferoğlu 2015: 12) kullanılan kelimeye Gümüşhane ağzında "hayır dua etmek, iyi dileklerde bulunmak" anlamlarıyla (Bulut 2018: 17) rastlanmaktadır.

bärk (ET) / berklik (GA): Kelime, "güçlü, sert" anlamlarıyla kullanılmıştır (Caferoğlu 2015: 39; Bulut 2018: 47).

bäzäklik (ET) / bezek (GA): Kelime, beze- fiil kökünden türemiş olup Eski Türkçede "süslenme yeri” (Caferoğlu 2015: 40), Gümüşhane ağzında ise "süs, ziynet" anlamlarıyla (Bulut 2018: 49) kullanılmıştır.

böçek (ET) / böcü-böce (GA): Kelime, "böcek, akrep, örümcek, bit vb.” anlamlarında kullanılmıştır (Gülensoy 2011: 169; Bulut 2018: 57).

budmak (ET) / buymak (GA): Eski Türkçede budmak şeklinde ve "donarak ölmek" anlamıyla (Gülensoy 2011: 188) kullanılan kelimeye Gümüşhane ağzında buymak şeklinde ve "çok üşümek" anlamıyla (Bulut 2018: 61) rastlanmaktadır.

bük (ET) / bük (GA): Kelime, "köşe, dönemeç" anlamlarıyla kullanılmıştır (Tekin 2000: 242; Bulut 2018: 61).

cırlamak: Eski Türkçede "türkü, nağme" anlamlarıyla kullanılan ır-yır kelimelerinden türeyerek Gümüşhane ağzında cırlamak şeklinde kullanılan kelime, bu ağız bölgesinde "ince ses çıkararak ağlamak, tiz sesle bağırıp çağırmak" anlamlarıyla kullanılmıştır (Gülensoy 2011: 203; Bulut 2018: 75). 
çasut (ET) / çaşıt (GA): Eski Türkçede “casus” anlamıyla kullanılan kelime, Gümüşhane ağzında da küçük bir ses değişikliğine uğrayarak aynı anlamını muhafaza etmiştir (Gülensoy 2011: 222; Bulut 2018: 89).

çat (ET) / çat (GA): Kelime, "iki dere veya iki yolun birleştiği yer, kavşak" anlamıyla kullanılmıştır (Gülensoy 2011: 222; Bulut 2018: 89).

çommak (ET) / çimmek (GA): Eski Türkçede çommak şeklinde ve "batmak, dalmak" anlamlarıyla (Gülensoy 2011: 243) kullanıldığı tespit edilen kelime Gümüşhane ağzında çimmek şeklinde ve "yıkanmak" anlamıyla (Bulut 2018: 104) kullanılmıştır.

değirmi: Bu kelime, Eski Türkçede tägirmi şeklinde ve "yuvarlak" anlamıyla (Gülensoy 2011: 272) kullanılmıştır. Gümüşhane ağzında ise değirmi şeklinde ve "yuvarlama" anlamıyla (Bulut 2018: 119) kullanıldığı görülmektedir.

ebe (ET) / ebe (GA): Kelime, Eski Türkçede ve Gümüşhane ağzında "büyükanne, nine” anlamlarıyla kullanılmıştır (Gülensoy 2011: 317; Bulut 2018: 140).

ägirmäk (ET) / eğirmek (GA): Kelime, "yün, pamuk vb. şeyleri bükerek iplik hâline getirmek" anlamıyla kullanılmıştır (Caferoğlu 2015: 69; Bulut 2018: 142).

äkä (ET) / eke (GA): Kelime, Eski Türkçede “abla” anlamıyla (Caferoğlu 2015: 70; Tekin 2000: 241) kullanılırken Gümüşhane ağzında "büyük, yetişkin, yaşlı" anlamlarıyla (Bulut 2018: 144) kullanılmıştır.

äm (ET) / em (GA): Kelime, "ilaç" anlamıyla kullanılmıştır (Caferoğlu 2015: 71; Bulut 2018: 148).

erinmäk (ET) / erinmek (GA): Kelime, "üşenmek, tembellik etmek" anlamlarıyla kullanılmıştır (Caferoğlu 2015: 74; Bulut 2018: 151).

ärk (ET) / erk (GA): Kelime, Eski Türkçede "kuvvet, kudret, güç" anlamlarıyla (Caferoğlu 2015: 74) kullanılırken Gümüşhane ağzında, "etkisi olma, sözü veya nazı geçme" anlamlarında kullanılır (Bulut 2018: 152).

ırğalmaḳ (ET) / ırgalamak (GA): Kelime, Eski Türkçede "sallanılmak, silkilmek" anlamlarıyla (Caferoğlu 2011: 87) kullanılırken, Gümüşhane ağzında "sarsmak, sallamak" anlamlarıyla (Bulut 2018: 250) kullanılmıştır.

ilki (ET) / ilkin (GA): Kelime, Eski Türkçede "birinci" anlamıyla (Orkun 2011: 804; Tekin 2000: 245) kullanılırken, Gümüşhane ağzında “önce” anlamıyla (Bulut 2018: 255) kullanılmıştır. 
kak (ET) / kaḳ (GA): Eski Türkçede "kurutulmuş nesne” anlamıyla (Gülensoy 2011: 356) kullanılan kak kelimesi Gümüşhane ağzında "soyulmadan dilimlenip kurutulan elma, armut kurusu” anlamıyla (Bulut 2018: 171) kullanılmıştır.

kakmak (ET) / kakalamak (GA): Eski Türkçedeki "hafifçe vurmak" anlamındaki kakfiilinden türeyen (Gülensoy 2011: 452) kelimenin Gümüşhane ağzında "itelemek, sarsmak, sokuşturmak" anlamlarıyla (Bulut 2018: 262) kullanıldığı görülmektedir.

kaş (ET) / kaş (GA): Kelime, Eski Türkçede "tepe" anlamıyla (Caferoğlu 2015: 170) kullanılırken, Gümüşhane ağzında "sarp kayalık, uçurum” anlamlarıyla (Bulut 2018: 266) kullanılmıştır.

kölük (ET) / gölük (GA): Eski Türkçede ve Gümüşhane ağzında "at, katır, eşek, beygir vb. yük taşıyan ve binilen hayvan" anlamıyla kullanılmıştır (Gülensoy 2011: 379; Bulut 2018: 210).

kulun (ET) / kulun (GA): Kelime, Eski Türkçede "tay” anlamıyla (Orkun 2011: 845; Tekin 2000: 249) kullanılırken, Gümüşhane ağzında "at ve eşek yavrusu, at ve eşeğin yeni doğmuş yavrusu" anlamlarıyla (Bulut 2018: 283) kullanılmıştır.

okımaḳ (ET) / okuyucu (GA): Orhun Kitabeleri'nde fiil olarak ve "çağırmak" anlamıyla (Tekin 2000: 250) kullanılmıştır. Gümüşhane ağzında aynı kökten türeyerek isim hâlinde ve "düğüne çağrı yapan kimse" anlamıyla (Bulut 2018: 315) kullanılmıştır. Yine Eski Türkçede okl- kökünden türeyen ve "çağrı, davetiye" anlamlarıyla (Gülensoy 2011: 619) kullanılan oḳunç kelimesi de bulunmaktadır.

örtük (ET) / örtük (GA): Kelime, "kapalı, örtülü” anlamlarıyla kullanılmıştır (Caferoğlu 2015: 153; Bulut 2018: 321).

ötürük (ET) / ötürük (GA): Kelime, "ishal” anlamıyla kullanılmıştır (Caferoğlu 2015: 155; Bulut 2018: 322).

sançmaḳ (ET) / sançmak (GA): Eski Uygur Türkçesi metinlerinde "delmek, saplamak" anlamlarıyla (Caferoğlu 2015: 196) kullanılan kelime, Gümüşhane ağzında "yılan, arı ve başka böceklerin sokması" anlamıyla (Bulut 2018: 337) görülmektedir. Orhun Kitabeleri'nde de aynı kelime “mızraklamak” anlamıyla (Tekin 2000: 252) kullanılmıştır. sıçġan (ET) / sıçan (GA): Kelime, "sıçan, fare" anlamlarıyla kullanılmıştır (Caferoğlu 2015: 202; Bulut 2018: 343).

suvamaḳ (ET) / suvarmak (GA): Kelime, Eski Uygur Türkçesi metinlerinde "sulamak" anlamıyla (Caferoğlu 2015: 213) kullanılmıştır. Gümüşhane ağzında Eski Türkçedeki 
kullanımıyla aynı kökten (suv: su kökü) türeyerek suvarmak şeklinde ve yine "sulamak" anlamıyla (Bulut 2018: 350) kullanılmıştır.

şapalak (ET) / şaplak (GA): Kelime, Eski Türkçede ve Gümüşhane ağzında "şap diye ses çıkaran tokat” anlamıyla kullanılmıştır (Gülensoy 2011: 838; Bulut 2018: 354).

täzäk (ET) / tezek (GA): Kelime, "sığır ve davar gübresinin yakacak odun yerine kullanılmak üzere kurutulanları" anlamıyla kullanılmıştır (Tekin 2000: 254; Bulut 2018: 369).

tor (ET) / tor (GA): Eski Türkçede "ağ, balık ağı, av ağı" anlamlarıyla (Caferoğlu 2015: 247) kullanılan kelimeye Gümüşhane ağzında "tavana meyve benzeri şeyler asmaya yarayan iplik, sicim, tel vb. ince şeylerden kafes biçiminde yapılmış örgü, ağ, torba" anlamiyla (Bulut 2018: 373) rastlanmaktadır.

tuluḳ (ET) / tuluk (GA): Kelime, "pekmez, peynir, yağ vb. şeyler koymaya yarayan ya da yayık olarak kullanılan deri, tulum" anlamıyla kullanılmıştır (Caferoğlu 2015: 252; Bulut 2018: 374).

tütün (ET) / tütün (GA): Kelimenin hem Eski Uygur Türkçesi metinlerinde hem de Gümüşhane ağzında "duman" anlamıyla kullanıldığ1 görülmektedir (Caferoğlu 2015: 260; Bulut 2018: 376).

uşak (ET) / uşak (GA): Bu kelime Eski Türkçede ve Gümüşhane ağzında "çocuk, ufak, küçük” anlamlarıyla kullanılmıştır (Gülensoy 2011: 972; Bulut 2018: 379).

utmaḳ (ET) / utulmak (GA): Kelime, Eski Uygur Türkçesinde "yenmek, kazanmak" anlamlarıyla (Caferoğlu 2015: 268) kullanılmıştır. Gümüşhane ağzında ise Eski Uygur Türkçesindeki kullanımla aynı kökten türeyerek utulmak şeklinde ve "oyunda yenilmek, yitirmek" anlamlarıyla (Bulut 2018: 379) kullanılmıştır.

ügra-ügre (ET) / uğra (GA): Eski Türkçede ügra-ügre şekillerinde ve "öz, lapa, bulamaç" anlamlanıyla (Caferoğlu 2015: 271, Paçacıŏlu 2016: 707) kullanılan kelimenin Gümüşhane ağzında uğra şeklinde ve "yufka aç1lırken hamurun tahtaya ve oklavaya yapışmaması için tahtaya serilen un" anlamıyla (Bulut 2018: 377) Eski Türkçedeki anlamına yakın bir biçimde kullanıldığı görülmektedir.

üläşmäk (ET) / üleşmek (GA): Kelime, "paylaşmak, bölüşmek" anlamlarıyla kullanılmıştır (Caferoğlu 2015: 272; Bulut 2018: 381). 
yarma (ET) / yarma (GA): Kelimenin hem Eski Uygur Türkçesi metinlerinde hem de Gümüşhane ağzında "iri bulgur" anlamıyla kullanıldığg görülmektedir (Caferoğlu 2015: 288; Bulut 2018: 393).

yavġan (Et) / yavan (GA): Kelime, "yersiz, yararsız söz" anlamlarıyla kullanılmıştır (Gülensoy 2011: 1090; Bulut 2018: 394).

yazı (ET) / yazı (GA): Bu kelime, “ova, düz yer” anlamlarında kullanılmıştır (Caferoğlu 2015: 291; Orkun 2011: 889; Bulut 2018: 395).

yılḳı (ET) / yılkı (GA): Eski Türkçede "at sürüsü” anlamıyla kullanılan kelime Gümüşhane ağzında da aynı anlamı muhafaza etmiştir (Caferoğlu 2015: 294; Orkun 2011: 894; Tekin 2000: 259; Bulut 2018: 389).

yumaḳ (ET) / yumak (GA): Kelime, "yıkamak, temizlemek” anlamlarıyla kullanılmıştır (Caferoğlu 2015: 305; Bulut 2018: 402). Aynı kelimeden türeyen yunmak kelimesinin de hem Eski Türkçede hem de Gümüşhane ağzında ortak bir şekilde kullanıldığ 1 görülmektedir.

\section{Sonuç}

Gümüşhane ili ve yöresi söz varlığında 105 adet Eski Türkçe kelime tespit edilmiştir. Bu kelimelerden 33 tanesi Türkçe Sözlük’te bulunmayan dolayısıyla Türkiye Türkçesi yazı dilinde kullanılmayan kelimelerdir. 22 tanesi çeşitli ses hadiselerinden ötürü Türkçe Sözlük’te şeklen bulunmayan kelimelerdir. 50 tanesi de Türkçe Sözlük’te bulunmasına rağmen Türkiye Türkçesi yazı dilinde yaygın bir biçimde kullanılmayan ve yavaş yavaş unutulmaya yüz tutmuş kelimelerdir. Eski Türkçede ve Gümüşhane ağzında aynı şekil fakat farklı anlam özellikleriyle kullanılan ana, atlak, ayamak, bar, basık, bidik, ĕglek, eğrek, ırgalamak, ilik, irtmek, kov, koyak, külek, kümek gibi birçok kelime de bulunmaktadir.

Bir dilin zenginliği bünyesinde barındırdığı kelime sayısı ile doğru orantılıdır. Kelimelerin bir dil içerisinde unutulup kaybolması o dilin fakirleşmesine ve de zamanla unutulmasına yol açabilmektedir. Anadili Türkçe olan bir milletin, kökeni Türkçe olan kelimelere daha fazla ağırlık vermesi ve o kelimelerin unutulmaması için çeşitli faaliyetlerde bulunması gerekmektedir. Ağızlar da, işte bu unutulmaya yüz tutmuş kelimelerin son yaşam alanı olarak müracaat edilmesi gereken temel kaynaklardır. Bu anlamda, Gümüşhane ili ve yöresi söz varlığında tespit edilen ve Türkçe Sözlük’te bulunmayan 33 adet Eski Türkçe kelime, Türkçenin kelime hazinesine eklenmesi bakımından önemlidir. Yine, Gümüşhane ağzında tespit edilen unutulmaya başlamış 50 
adet kelimenin de yaşatılması için çeşitli çalışmalar yapılmalıdır. Dolayısıyla ağızlardaki söz varlığı üzerine yapılacak bu ve bunun gibi çalışmalar Türkiye Türkçesi kelime hazinesinin canlı tutulmasına ve her biri binlerce yıllık birçok kelimenin Türkçenin zenginliği içerisinde yerini almasına vesile olacaktır.

\section{Kaynakça}

BULUT, Serdar (2018). Gümüşhane Illi ve Yöresi Ağızları Söz Varlı̆̆ı, Ankara: Gazi Kitabevi.

CAFEROĞLU, Ahmet (2015). Eski Uygur Türkçesi Sözlüğü, Ankara: Türk Dil Kurumu Yayınları.

DİLÇİN, Cem (1983). Yeni Tarama Sözlüğü, Ankara: Türk Dil Kurumu Yayınları.

DOĞAN, D. Mehmet (2001). Büyük Türkçe Sözlük, Ankara: Vadi Yayınları.

ERASLAN, Kemal (2012). Eski Uygur Türkçesi Grameri, Ankara: Türk Dil Kurumu Yayınları.

ERCİLASUN, A. Bican ve Ziyat AKKOYUNLU (2018). Dîvânu Lugâti't-Türk, Ankara: Türk Dil Kurumu Yayınları.

ERGİN, Muharrem (1999). Orhun Abideleri, İstanbul: Boğaziçi Yayınları.

ERGİN, Muharrem (2003). Türk Dil Bilgisi, İstanbul: Bayrak Basım / Yayım / Tanitım.

EROL, Hülya Arslan (2014). Eski Türkçeden Eski Anadolu Türkçesine Anlam Değişmeleri, Ankara: Türk Dil Kurumu Yayınları.

GABAIN, A. Von (2000). Eski Türkçenin Grameri, Ankara: Türk Dil Kurumu Yayınlar1.

GÜLENSOY, Tuncer (2011). Türkiye Türkçesindeki Türkçe Sözcüklerin Köken Bilgisi Sözlüğü, Cilt: I-II, Ankara: Türk Dil Kurumu Yayınları.

GÜLSEVIN, Gürer (2005). "Ağız Araştırmalarımızda Yaygınlaşmış Yanlışlıklar "üzüm / yüzüm; öllük / höllük" türeme mi düşme mi?", Türk Dünyası Íncelemeleri Dergisi, Cilt: V, Sayı: 2, 207-213.

GÜLSEVIN, Gürer (2011). Eski Anadolu Türkçesinde Ekler, Ankara: Türk Dil Kurumu Yayınları. 
HACIEMINOĞLU, Necmettin (2003). Karahanlı Türkçesi Grameri, Ankara: Türk Dil Kurumu Yayınları.

KARAHAN, Leyla (2017). Anadolu Ağızlarının Sinıflandırılması, Ankara: Türk Dil Kurumu Yayınları.

Türk Dil Kurumu (1998). Türkçe Sözlük, Cilt: I-II, Ankara: Türk Dil Kurumu Yayınları.

Türk Dil Kurumu (2009). Derleme Sözlüğü, Cilt: I-II-III-IV-V-VI, Ankara: Türk Dil Kurumu Yayınları.

Türk Dil Kurumu (2009). Tarama Sözlüğü, Cilt: I-II-III-IV-V-VI-VII-VIII, Ankara: Türk Dil Kurumu Yayınları.

ÖLMEZ, Mehmet (2017). Köktürkçe ve Eski Uygurca Dersleri, İstanbul: Kesit Yayınları.

PAÇACIOĞLU, Burhan (2016). Türkçenin VIII.-XVI. ürkçenin VIII.-XVI. Yüzyıllar Arasında Sözcük Dă̆arcı̆̆g, İstanbul: Kesit Yayınları.

SEREBRENNIKOV, Boris ve Ninel GADJIEVA (2011). Türk Yazı Dillerinin Tarihi Grameri, çev. Tevfik Hacıyev-Mustafa Öner, Ankara: Türk Dil Kurumu Yayınları.

SÜMER, Faruk (1992). Oğuzlar-Türkmenler, İstanbul: Türk Dünyas1 Araştırmaları Vakfı.

ŞEN, Serkan (2016). Eski Uygur Türkçesi Dersleri, İstanbul: Kesit Yayınları.

TEKİN, Talat (2000). Orhon Türkçesi Grameri, Ankara: Sanat Kitabevi.

TELLİ, Burak (2017). "Güneydoğu Anadolu Bölgesi Ağılarında Geçen İkilemeler Üzerine Bir Değerlendirme", Hikmet-Akademik Edebiyat Dergisi (Journal of Academic Literature), Say1: 6, 133-149.

ÜNLÜ, Eren (2015). Gümüşhane İli Şiran ve Köse İlçeleri Ağızları, (Yayımlanmamış Yüksek Lisans Tezi), Adıyaman Üniversitesi Sosyal Bilimler Enstitüsü, Adiyaman.

ÜNLÜ, Suat (2012). Karahanlı Türkçesi Sözlüğü, Konya: Eğitim Kitabevi. 